ISSN 1678-3921

Journal homepage: www.embrapa.br/pab

For manuscript submission and journal contents, access: www.scielo.br/pab

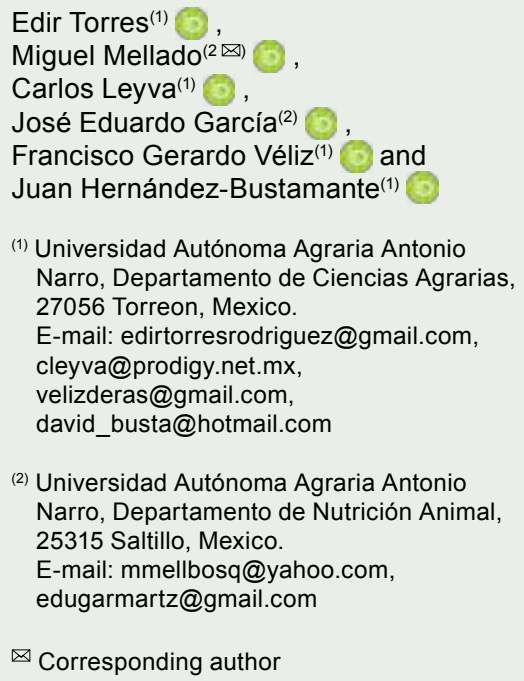

(2) Universidad Autónoma Agraria Antonio Narro, Departamento de Nutrición Animal, 25315 Saltillo, Mexico.

\section{Serum metabolites and body condition score associated with metritis, endometritis, ketosis, and mastitis in Holstein cows}

\begin{abstract}
The objective of this work was to identify the serum metabolites and the body condition score (BCS) of Holstein cows associated with the occurrence of periparturient diseases, when under heat stress. Blood samples were collected from 181 cows one week after calving, and the BCS was recorded at calving. Cows with $\beta$-hydroxybutyrate (BHBA) concentration $\geq$ $0.8 \mathrm{mmol} \mathrm{L}^{-1}$ were 2.2 times more likely to develop metritis and 4.4 times more likely to develop clinical endometritis (CE). Cows with serum creatinine levels $\geq 2.0 \mathrm{mg} \mathrm{dL}^{-1}$ showed 2.2 and 4.5 greater risk $(\mathrm{p} \leq 0.05)$ of suffering from metritis and $\mathrm{CE}$, respectively, during the current lactation. The odds of metritis and CE occurrence were 2.7 and 4.6 times greater $(\mathrm{p}<0.01)$ in cows with serum total protein (TP) $\geq 5.0 \mathrm{mg} \mathrm{dL}^{-1}$. Cows with serum glucose levels $\leq 70 \mathrm{mg} \mathrm{dL}^{-1}$ and non-esterified fatty acids (NEFAs) $\geq 0.5$ had 9.4 and 8.8 times greater odds of developing clinical ketosis, respectively, than cows with lower glucose and NEFA blood levels. The strategic use of metabolic tests to monitor transition Holstein cows, aiming to prevent some postpartum diseases due to heat stress, should focus on blood BHBA, NEFAs, glucose, creatinine, and TP. Additionally, the $\mathrm{BCS} \leq 3.2$ should be avoided to prevent endometritis.
\end{abstract}

Index terms: $\beta$-hydroxybutyrate, clinical ketosis, creatinine, endometritis, non-esterified fatty acids.

\section{Metabólitos séricos e escore de condição corporal associados a metrite, endometrite, cetose e mastite em vacas da raça Holandesa}

Resumo - O objetivo deste trabalho foi identificar os metabólitos séricos e o escore de condição corporal (BCS) de vacas Holandesas associados à ocorrência de doenças periparturientes, quando sob estresse térmico. Amostras de sangue foram coletadas de 181 vacas uma semana após o parto, e o BCS foi determinado no parto. Vacas com concentração de $\beta$-hidroxibutirato (BHBA) $\geq 0,8 \mathrm{mmol} \mathrm{L}^{-1}$ tinham 2,2 vezes mais chances de desenvolver metrite e 4,4 vezes mais chances de desenvolver endometrite clínica (EC). Vacas com níveis séricos de creatinina $\geq 2,0 \mathrm{mg} \mathrm{dL}^{-1}$ apresentaram 2,2 e 4,5 vezes maior risco $(\mathrm{p} \leq 0,05)$ de sofrer de metrite e EC, respectivamente, na lactação atual. As chances de metrite e EC foram 2,7 e 4,6 vezes maiores ( $p<0,01)$ em vacas com proteína total sérica $(\mathrm{TP}) \geq 5,0 \mathrm{mg} \mathrm{dL}^{-1}$. Vacas com níveis séricos de glicose $\leq 70 \mathrm{mg} \mathrm{dL}^{-1}$ e ácidos graxos não esterificados (NEFAs) $\geq 0,5$ tiveram 9,4 e 8,8 vezes mais chances de desenvolver cetose clínica, respectivamente, que vacas com níveis mais baixos de glicose e NEFAs no sangue. O uso estratégico de testes metabólicos para monitorar vacas Holandesas em 
transição, para prevenir algumas doenças pós-parto devido ao estresse térmico, deve se concentrar em BHBA, NEFAs, glicose, creatinina e TP no sangue. Além disso, o $\mathrm{BCS} \leq 3,2$ deve ser evitado para prevenir a endometrite.

Termos para indexação: $\beta$-hidroxibutirato, cetose clínica, creatinina, endometrite, ácidos graxos não esterificados.

\section{Introduction}

During the initiation of lactation, dairy cows go through a period of negative energy balance, which results in an increased mobilization of fat and protein, to meet the demands of high milk production during the first weeks of lactation (Macrae et al., 2019). Main nutritional, physiological, metabolic, and immunological changes occur within this time frame as the cow moves from a non-lactating state to the onset of copious colostrum and milk synthesis (Sundrum, 2015). Metabolically, cows must adjust to the marked increase in nutrient requirements for high milk production and the resumption of the reproductive function in the ensuing lactation (Bisinotto et al., 2012).

Imbalances between nutrient demand and supply at the beginning of lactation due to an insufficient dry matter intake lead to an ample adaptation and regulation of the metabolism (Fiore et al., 2018). This great metabolic challenge to high-yielding dairy cows results in drastic changes in their metabolic profiles, which can be used to evaluate the health status of fresh cows (Macrae et al., 2006) and to detect risk factors for metabolic and periparturient clinical diseases (Hammon et al., 2006; McArt et al., 2013). Some periparturient diseases disturb metabolism processes, resulting in alterations that can be taken as metabolic signatures. In a diseased state, the concentration of these metabolites is modified, providing information on disease pathophysiology (Shin et al., 2015).

Previous studies have shown that plasma glucose in early lactation is a reliable predictor for metritis and endometritis diagnoses in dairy cows (Bicalho et al., 2017). Elevated serum non-esterified fatty acid (NEFA) concentrations within one week before parturition were associated with an increased risk of metritis, retained placenta, and displaced abomasum after calving (Chapinal et al., 2011). Postpartum serum NEFA concentration has also been associated with an increased risk of metritis development, displaced abomasum, clinical ketosis, and retained placenta (Ospina et al., 2010).

The occurrence of postpartum diseases in dairy cattle can also be related to the rate of loss and regain of body condition during the post-calving period (Kadivar et al., 2014), possibly due to the association between the excessive loss of body energy reserves in dairy cows after calving and a depressed immune function (Ohtsuka et al., 2008). This impairment of the immune function and endocrine system is exacerbated by a high ambient temperature (Thompson et al., 2014), enhancing the susceptibility of the animal to various diseases (Das et al., 2016).

However, little is known about the association between blood metabolites and peripartum diseases in cows suffering heat stress during the peri-calving period. Therefore, the identification of certain metabolites during the puerperal period in heatstressed cows could help to gain a more comprehensive understanding of how metabolite profiles are associated with different postpartum diseases in dairy cows (Dervishi et al., 2016). In this context, metabolic signatures for postpartum disorders in dairy cows, whose basic physiological mechanisms are altered by an increase in environmental temperature, could be key to identifying the biomarkers for these diseases.

The objective of this work was to identify the serum metabolites and the body condition score of Holstein cows associated with the occurrence of periparturient diseases, when under heat stress.

\section{Materials and Methods}

The study design was reviewed and approved by Universidad Autónoma Agraria Antonio Narro, located in Mexico, prior to the beginning of the research. One hundred and ninety-two Holstein cows were recruited from an intensive commercial 2,500-Holstein cow farm in northern Mexico $\left(25^{\circ} 41^{\prime} 43^{\prime \prime} \mathrm{N}, 103^{\circ} 13^{\prime} 42^{\prime \prime} \mathrm{W}\right)$; however, since 11 cows were destined for culling shortly after calving, only 181 cows remained in the trial. The dairy farm is located in an area characterized by high daytime temperatures of around $40^{\circ} \mathrm{C}$ in spring, summer, and fall and by an intense solar radiation associated with a low relative humidity (mean temperature-humidity index of 80.0; range from 69.8 to 89.0 ), with an average annual precipitation of $230 \mathrm{~mm}$. 
Cows had 1 to 6 lactations $(78,62,21,14,4$, and 2 for the first to sixth parities) and a body condition score (BCS) ranging from 2.75 to 4.0 at calving, considering a 5-point scale (Edmonson et al., 1989). The herd's rolling herd average was $12,742 \mathrm{~kg}$. Cows were fed a total mixed ration (TMR) formulated to meet or exceed the predicted nutrient requirements of a lactating Holstein cow yielding $40 \mathrm{~kg}$ milk per day and with $640 \mathrm{~kg}$ body weight (NRC, 2001). The TMR consisted of $50 \%$ forage and $50 \%$ concentrate for ad libitum intake. Cows were housed in large, open-air, dirt-floor pens and they had unlimited access to fresh water. The BCS was determined on days 0,30 , and 60 of the trial using the previously mentioned scale.

One blood sample per cow was obtained during the first week ( $6 \pm 2$ days; mean \pm standard deviation) postpartum from the median and caudal coccygeal vessels and then placed into 10-mL BD Vacutainer evacuated tubes (Becton, Dickinson and Company, Franklin Lakes, NJ, USA), without anticoagulant, connected to a $2.5-\mathrm{cm} 20$-gauge needle. The ventral tail site was selected because venipuncture is quick and requires minimal restraint of the animal. Although it was unknown if the obtained samples were from venous or arterial blood, differences in the arterialvein chemical compositions across the cow's tail are considered to be insignificant (Zhang et al., 2016). Blood sampling was carried out from May to July 2017, and blood was collected when the cows were restrained in the feeding rack and at least $60 \mathrm{~min}$ had elapsed between milking and blood sampling. Each blood sample was set to clot in an upright position for $30 \mathrm{~min}$ to 1 hour before being centrifuged at $1,200 \times$ $g$ for $20 \mathrm{~min}$ at $4^{\circ} \mathrm{C}$. Blood serums were separated and stored in $2-\mathrm{mL}$ vials at $-20^{\circ} \mathrm{C}$ until further use.

Immediately after sample collection, an aliquot of blood was removed from the evacuated tubes using a syringe and entered into the Precision Xtra BHBA hand-held meter (Abbott Laboratorios, Mexico City, Mexico) to determine BHBA at the cow's side. A blood BHBA value of $\geq 3.0 \mathrm{mmol} \mathrm{L}^{-1}$ was used as a cutoff to identify clinical ketosis (McArt et al., 2013). Serum metabolites were determined using the Coleman Junior II spectrophotometer (Coleman Instruments, Inc., Maywood, IL, USA). Serum total protein concentration was obtained with a kit based on the bicinchoninic acid reagent, with bovine serum albumin as a protein standard (Pierce Chemical, Rockford, IL,
USA). Glucose was assayed with kit number 315-500 (Sigma-Aldrich Chemical Co., St. Louis, MO, USA), based on glucose oxidase, and urea was quantified using kit 640-A, based on urease (Sigma-Aldrich Co., St. Louis, MO, USA).

Creatinine was measured in serum using the QuantiChrom Creatinine Assay Kit - DICT-500 (BioAssay Systems, Hayward, CA, USA), whereas serum cholesterol was determined with the EnzyChrom Cholesterol Assay Kit - ECCH-100 (BioAssay Systems, Hayward, CA, USA). The NEFA-HR(2) commercial kit (Fujifilm Wako Diagnostics U.S.A. Corporation, Mountain View, CA, USA) was used to obtain NEFA concentrations. Alkaline phosphatase activity was estimated in a spectrophotometer at wavelengths of $340 \mathrm{~nm}$ (Analyticon Biotechnologies AG, Lichtenfels, Germany). All determinations were made in duplicate. The intra-assay coefficients of variation for $\beta$-hydroxybutyrate, total protein, glucose, creatinine, cholesterol, blood urea nitrogen (BUN), alkaline phosphatase, and NEFAs were 11.2, 2.4, 2.7, $8.1,9.2,1.6,4.3$, and 6.3 , respectively.

Dystocia was defined as a prolonged difficult birth requiring assisted extraction, classified as score 4, according to Hansen et al. (2004). Assistance was provided to heifers without calving progress around 90 min after the amniotic sac or the feet appeared outside the vulva (Schuenemann et al., 2011). Retained placenta was defined as the failure to expel the placenta within 24 hours after parturition. During the 40 days postpartum, the research team performed reproductive health checks on all cows weekly, which included the examination of the uterus by transrectal palpation in order to detectclinical metritis and clinical endometritis. Cows were considered to have puerperal metritis when they showed inflammation of the uterus (increased uterine volume and tense uterine wall), as well as a purulent fetid, watery, and brownish discharge with fetid odor and the presence of pus during the first three weeks after calving, without fever or toxemia (Sheldon et al., 2006). The cows with clinical endometritis had a purulent ( $>50 \%$ pus) discharge between 20 and 33 days postpartum or a mucopurulent (approximately 50\% pus and $50 \%$ mucus) discharge in their vagina 21 to 33 days postpartum and endometrial thickness without systemic clinical signs (Gobikrushanth et al., 2016). During the study period, $5.5 \%$ of the cows (10 out of 181) with metritis presented clinical endometritis. 
Clinical ketosis was diagnosed based on the BHBA levels one week postpartum, determined with the Precision Xtra BHBA hand-held meter (Abbott Laboratorios, Mexico City, Mexico) at the cow's side; blood values $\geq 3.0 \mathrm{mmol} \mathrm{L}^{-1}$ indicated clinical ketosis. The California mastitis (CMT) test kit (ImmuCell, Portland, ME, USA) was used to detect suppurative mastitis on all the quarter foremilk samples collected from the cow's side, and the test results were read and recorded by one trained technician. CMT was considered positive to reactions greater than a score of 1 , considering the scale: 0 , no reaction or trace; 1 , weak positive; 2 , moderate positive; and 3 , strong positive. The test was conducted on all fresh cows and heifers by the third milking, whereas additional tests were performed on all cows biweekly until 300 days postpartum.

A multivariable logistic regression model was fitted with postpartum diseases as dependent variables using the Proc Logistic of SAS (SAS Institute, Inc., Cary, NC, USA). Serum glucose, creatinine, total protein, BUN, NEFAs, BHBA, alkaline phosphatase, and BCS at 0 , 30 , and 60 days post-calving were evaluated as initial explanatory variables in the removal model. A stepwise backward selection process was used to construct the final models, taking $\mathrm{p}<0.15$ for the retention of a variable in the model. The variables lactation number, season of calving, occurrence of retained placenta, and dystocia were forced into the model as covariates. Serum metabolites and BCS, as diagnostic tools for postpartum diseases, were analyzed with receiver operating characteristic (ROC) curves, also using Proc Logistic of SAS. Sensitivity was considered the proportion of animals diagnosed with metritis, above a given threshold, and specificity, the proportion of animals diagnosed as without metritis, below a given threshold. The critical threshold was the point on the ROC curve that had the highest combined sensitivity and specificity. In all analyses, results were considered significant at $5 \%$ probability.

\section{Results and Discussion}

The partial incidences of dystocia, retained placenta, metritis, clinical endometritis, clinical ketosis, and suppurative mastitis were $5.3,6.9,16.4,18.2,4.8$, and $13.2 \%$, respectively. Of the cows suffering retained placenta, $16 \%$ also presented metritis, whereas $11.3 \%$ of the cows with retained placenta showed clinical endometritis. Surprisingly, the incidence of suppurative mastitis was much lower than $20 \%$ in intensive dairy operations in temperate climates (Hiitiö et al., 2017), although the increase in ambient temperature causes an increased incidence of mastitis in cows (Jingar et al., 2014); in tropical environments, the incidence of suppurative mastitis may be as high as $46 \%$ (Busanello et al., 2017). The incidence of all other peripartum diseases was close to the values found for dairy cows in intensive systems (Ribeiro et al., 2013).

Serum BHBA $\geq 0.8 \mathrm{mmol} \mathrm{L}^{-1}$ concentration in the first week post-calving was associated with a 2.2-fold increase in the occurrence of metritis (Table 1), which is consistent with the findings of Duffield et al. (2009). The mechanism explaining why cows diagnosed with metritis had elevated serum BHBA concentrations could be that they were suffering a poor adaptive response to the onset of lactation and to the resulting negative energy balance. The effect of elevated serum BHBA levels on metritis risk seems to be mediated by the impacts of hyperketonemia on the immune function (Hoeben et al., 2000; Zarrin et al., 2014).

The optimal predictor cut point obtained for the discrimination between healthy and puerperal metritic cows was $1.2 \mathrm{mmol} \mathrm{L}^{-1}$. This finding shows that serum BHBA has a predictive ability to discriminate between cows with metritis.

Cows with serum creatinine concentrations $\geq 2.0 \mathrm{mg}$ $\mathrm{dL}^{-1}$ postpartum were about 2.2 times more likely to present metritis than those with a lower concentration of this metabolite (Table 1). To discriminate between healthy and metritic cows (area under ROC curve $=$ 0.70 ), an optimal predictor cut point of $2.1 \mathrm{mg} \mathrm{dL}^{-1}$ was used. High blood creatinine concentrations indicate prolonged active-tissue protein catabolism (Carlotti et al., 2008), and this protein deficiency impairs both humoral and cell-mediated immunity, predisposing the animal to diseases (Titgemeyer \& Loest, 2001).

A significantly increased risk of metritis was also observed for cows with serum total protein $\geq 5.0 \mathrm{mg}$ $\mathrm{dL}^{-1}$. For an optimizing prediction of subsequent metritis, the threshold was $5.3 \mathrm{mg} \mathrm{dL}^{-1}$ for total protein. Moreover, the area under the ROC curve suggests fair discrimination, i.e., the ability to diagnose cows with and without metritis based on metabolites. It should be noted that the activation of the immune response of cows after an infection is indicated by increased proteins and globulin in their blood (Cray et al., 2009), mainly of

Pesq. agropec. bras., Brasília, v.55, e01308, 2020

DOI: 10.1590/S1678-3921.pab2020.v55.01308 
serum albumin and immunoglobulins, implicated in defense mechanisms (Tsenkova et al., 2001).

The obtained results suggest that both high serum creatinine and total protein levels one week postpartum allow distinguishing a healthy dairy cow from another suffering clinical endometritis. In agreement with the findings of the present study, Tóthová et al. (2017) observed that the serum total protein level was higher in cows with uterine infections than in healthy ones. In early lactation, the nutrient requirement for cows to reach their maximum genetic potential for milk yield causes metabolic changes, such as in the concentration of metabolites, which, when related to protein catabolism, are relevant for the immune function.

Serum BHBA levels $\geq 0.08 \mathrm{mmol} \mathrm{L}^{-1}$ in the first week postpartum were associated with a four-fold increase in the risk of clinical endometritis. This result is not in alignment with that of Kaufmann et al. (2010), who did not detect a relationship between blood BHBA and clinical endometritis. However, in a field study, high blood concentrations of BHBA were observed during early lactation in cows with clinical endometritis, when compared with healthy ones (Hammon et al., 2006). The deleterious effect of high levels of serum BHBA on the occurrence of clinical endometritis is related to the high blood levels of this metabolite, which weaken immune response by impairing the proliferation of lymphocytes (Franklin et al., 1991) and the proliferation of bone marrow cells (Hoeben et al., 2000).
Clinical endometritis was 3.5 times more likely in cows with serum glucose $\leq 70 \mathrm{mg} \mathrm{dL}^{-1}$ (Table 2). This response is similar to that reported by Bicalho et al. (2017), who concluded that a low serum glucose concentration was associated with the occurrence of the disease. A possible explanation is that the high demand for glucose for the synthesis of milk lactose at the beginning of lactation may reduce glucose availability for other body tissues, including those involved in the postpartum immune defense. This could be due to the contribution of low blood glucose to immunosuppression during the periparturient period (Ingvartsen \& Moyes, 2013).

Cows with serum creatinine $\geq 2.0$ were 4.5 times more likely of suffering clinical endometritis than those with low blood levels of this metabolite. The serum metabolite more strongly associated with the disease was total protein, since cows with total protein $\geq 5.0 \mathrm{mg} \mathrm{dL}^{-1}$ were 4.6 times more likely of experiencing clinical endometritis than those with a lower blood level postpartum.

The incidence of clinical endometritis increased about two times in cows with serum cholesterol levels $\leq 110 \mathrm{mg} \mathrm{dL}^{-1}(\mathrm{p}<0.05)$, which is in line with previous studies that reported the relationship between uterine diseases and cholesterol blood levels (Kaneene et al., 1997). Insufficient nutrient intake during the beginning of lactation (Wankhade et al., 2017) reduces circulatory cholesterol levels (Kessler et al., 2014), and the challenge of the negative energy balance disturbs

Table 1. Associations of postpartum serum $\beta$-hydroxybutyrate and of creatinine concentrations measured one week after calving with the risk of subsequent metritis post-calving in high-yielding Holstein cows $(n=181)$. The epidemiological sensitivity (Sen) and specificity (Spec) for predicting cows at risk of developing metritis were obtained from a receiver operating characteristic (ROC) curve.

\begin{tabular}{|c|c|c|c|c|c|c|c|}
\hline Serum metabolite & $\begin{array}{c}\text { Incidence } \\
\%(\mathrm{n})\end{array}$ & $\begin{array}{l}\text { Odds ratio } \\
(\mathrm{OR})\end{array}$ & OR at $95 \% \mathrm{CI}^{(1)}$ & p-value & Cut point ${ }^{(2)}$ & $\begin{array}{l}\text { Sen } \\
(\%)\end{array}$ & $\begin{array}{c}\text { Spec } \\
(\%)\end{array}$ \\
\hline$\beta$-hydroxybutyrate $\left(\mathrm{mmol} \mathrm{L}^{-1}\right)$ & & & & 0.05 & $1.2 \mathrm{mmol} \mathrm{L}^{-1}$ & 75 & 42 \\
\hline$\leq 0.8$ & $12.0(11 / 92)$ & Reference $^{(3)}$ & & & & & \\
\hline$\geq 0.8$ & $22.5(20 / 89)$ & 2.2 & $1.0-4.8$ & & & & \\
\hline Creatinine ( $\left.\mathrm{mg} \mathrm{dL}^{-1}\right)$ & & & & 0.05 & $2.1 \mathrm{mg} \mathrm{dL}^{-1}$ & 59 & 39 \\
\hline$\leq 2.0$ & $12.9(12 / 93)$ & Reference & & & & & \\
\hline$\geq 2.0$ & $26.1(23 / 88)$ & 2.2 & $1.0-4.9$ & & & & \\
\hline Total protein $\left(\mathrm{mg} \mathrm{dL}^{-1}\right)$ & & & & 0.01 & $5.3 \mathrm{mg} \mathrm{dL}^{-1}$ & 56 & 38 \\
\hline$\leq 5.0$ & $10.2(9 / 88)$ & Reference & & & & & \\
\hline$\geq 5.0$ & $23.7(22 / 93)$ & 2.7 & $1.2-6.3$ & & & & \\
\hline
\end{tabular}

${ }^{(1)} \mathrm{CI}$, confidence interval. ${ }^{(2)} \mathrm{Cut}$ point, herd alarm level with an increased probability of metritis based on the serum metabolite concentration in transition Holstein cows. ${ }^{(3)}$ Odds ratio reference value. 
the immune function, predisposing dairy cows to uterine diseases (Esposito et al., 2014).

An additional risk factor for clinical endometritis was the BCS 30 days postpartum. A change in the $\mathrm{BCS}$ is an indirect measurement of fat metabolism and, therefore, is associated with NEFAs and BHBA (Roche et al., 2009). Although blood metabolites indicative of the nutritional status of dairy cows are more objective than the BCS, the obtained data support the view that this score could be a factor of potential effect on the disease.

For all variables, the cut-off point was $\geq 0.5$ and $\leq 0.7$, which was considered fair and accurate; none of the lower points of the confidence intervals was $\leq 0.5$. For an initial screening, these cut-offs points had an adequate sensitivity and could be used in a practical scheme for the control of periparturient diseases in high-yielding Holstein cows.

Low serum glucose levels one week post-calving were identified as a reliable indicator for the detection of clinical ketosis among the evaluated metabolites, since at $\geq 3.0 \mathrm{mmol} \mathrm{L}^{-1}$ BHBA this disease was 9.4 times more likely in cows with serum glucose concentration $\leq 70$ $\mathrm{mg} \mathrm{dL}^{-1}$ (Table 3). Other researchers also found that cows with ketosis had lower levels of glucose early in lactation, compared with nonketotic ones (Shin et al., 2015).

Compared with all other cows with serum NEFAs $\leq 0.5 \mathrm{mEq} \mathrm{L}^{-1}$, those with serum NEFAs $\geq 0.5 \mathrm{mEq} \mathrm{L}^{-1}$ one week postpartum were 8.8 times more likely to have clinical ketosis. Both serum BHBA and NEFA levels during the first week of lactation were able to discriminate cows subsequently presenting the disease, with an area under the ROC curve varying from 69 to $73 \%$. The sensitivity of $63 \%$ for NEFAs indicates that an optimum threshold value of $0.31 \mathrm{mEq} \mathrm{L}^{-1}$ during the first week post-partum could correctly identify $63 \%$ of the ketotic cows.

NEFAs are common indicators of the energy metabolism and the extent of fat mobilization; low serum glucose and high NEFAs particularly indicate metabolic

Table 2. Associations of various postpartum serum metabolite concentrations measured one week after calving and of body condition score (BCS) at parturition with the risk of subsequent endometritis post-calving in high-yielding Holstein cows $(\mathrm{n}=181)$. The epidemiological sensitivity (Sen) and specificity (Spec) for predicting cows at risk of developing endometritis were obtained from a receiver operating characteristic (ROC) curve.

\begin{tabular}{|c|c|c|c|c|c|c|c|}
\hline Variable & Incidence $\%(\mathrm{n})$ & Odds ratio (OR) & OR at $95 \% \mathrm{CI}^{(1)}$ & $\mathrm{p}$-value & Cut point ${ }^{(2)}$ & Sen $(\%)$ & Spec (\%) \\
\hline$\beta$-hydroxybutyrate $\left(\mathrm{mmol} \mathrm{L}^{-1}\right)$ & & & & 0.001 & $1.1 \mathrm{mmol} \mathrm{L}^{-1}$ & 74 & 44 \\
\hline$\leq 0.8$ & $10.9(10 / 92)$ & Reference $^{(3)}$ & & & & & \\
\hline$\geq 0.8$ & $34.8(31 / 89)$ & 4.4 & $2.0-9.6$ & & & & \\
\hline Glucose (mg dL $\left.{ }^{-1}\right)$ & & & & 0.001 & $66 \mathrm{mg} \mathrm{dL}^{-1}$ & 63 & 39 \\
\hline$\geq 70$ & $12.2(11 / 90)$ & Reference & & & & & \\
\hline$\leq 70$ & $33.0(30 / 91)$ & 3.5 & $1.6-7.6$ & & & & \\
\hline Creatinine $\left(\mathrm{mg} \mathrm{dL}^{-1}\right)$ & & & & 0.001 & $2.1 \mathrm{mg} \mathrm{dL}^{-1}$ & 60 & 29 \\
\hline$\leq 2.0$ & $10.8(10 / 93)$ & Reference & & & & & \\
\hline$\geq 2.0$ & $35.2(31 / 88)$ & 4.5 & $2.1-9.1$ & & & & \\
\hline Total proteins $\left(\mathrm{mg} \mathrm{dL}^{-1}\right)$ & & & & 0.001 & $5.53 \mathrm{mg} \mathrm{dL}^{-1}$ & 62 & 34 \\
\hline$\leq 5.0$ & $10.2(9 / 88)$ & Reference & & & & & \\
\hline$\geq 5.0$ & $34.4(32 / 93)$ & 4.6 & $2.1-10.4$ & & & & \\
\hline Cholesterol $\left(\mathrm{mg} \mathrm{dL}^{-1}\right)$ & & & & 0.031 & $108 \mathrm{mg} \mathrm{dL}^{-1}$ & 61 & 34 \\
\hline$\geq 110$ & $15.7(14 / 89)$ & Reference & & & & & \\
\hline$\leq 110$ & $29.3(27 / 92)$ & 2.2 & $1.1-4.6$ & & & & \\
\hline BCS 30 days postpartum & & & & 0.005 & 3.25 units & 54 & 29 \\
\hline$\geq 3.2$ & $13.6(12 / 88)$ & Reference & & & & & \\
\hline$\leq 3.2$ & $31.2(29 / 93)$ & 2.9 & $1.4-6.1$ & & & & \\
\hline
\end{tabular}

${ }^{(1)} \mathrm{CI}$, confidence interval. ${ }^{(2)} \mathrm{Cut}$ point, herd alarm level with an increased probability of endometritis based on the serum metabolite concentration in Holstein transition cows. ${ }^{(3)}$ Odds ratio reference value. 
Table 3. Associations of postpartum serum glucose and of non-esterified fatty acid (NEFA) concentrations measured one week after calving with the risk of subsequent ketosis post-calving in high-yielding Holstein cows $(\mathrm{n}=181)$. The epidemiological sensitivity (Sen) and specificity (Spec) for predicting cows at risk of developing clinical ketosis were obtained from a receiver operating characteristic (ROC) curve.

\begin{tabular}{|c|c|c|c|c|c|c|c|}
\hline Variable & Incidence $\%(\mathrm{n})$ & Odds ratio (OR) & OR at $95 \% \mathrm{CI}^{(1)}$ & p-value & Cut point ${ }^{(2)}$ & Sen $(\%)$ & Spec (\%) \\
\hline Glucose $\left(\mathrm{mg} \mathrm{dL}^{-1}\right)$ & & & & 0.035 & $66.2 \mathrm{mg} \mathrm{dL}^{-1}$ & 57 & 30 \\
\hline$\geq 70$ & $1.1(1 / 90)$ & Reference $^{(3)}$ & & & & & \\
\hline$\leq 70$ & $9.9(9 / 91)$ & 9.4 & $1.2-75.8$ & & & & \\
\hline NEFAs $\left(m E q L^{-1}\right)$ & & & & 0.041 & $0.31 \mathrm{mEq} \mathrm{L}^{-1}$ & 63 & 30 \\
\hline$\leq 0.5$ & $1.1(1 / 89)$ & Reference & $1.2-10.2$ & & & & \\
\hline$\geq 0.5$ & $9.8(9 / 92)$ & 8.8 & $1.2-70$ & & & & \\
\hline
\end{tabular}

${ }^{(1)} \mathrm{CI}$, confidence interval. ${ }^{(2)} \mathrm{Cut}$ point, herd alarm level with an increased probability of ketosis based on the serum metabolite concentration in Holstein transition cows. ${ }^{(3)}$ Odds ratio reference value.

difficulties with energy balance and, consequently, intense lipolysis. During the state of negative energy balance (NEB), gluconeogenesis is enhanced and a large portion of blood NEFAs is converted into ketone bodies in the liver hepatocytes (Gordon et al., 2013). Studies have shown that it is not NEB itself, but the inadequate metabolic adaptation that contributes to the development of ketosis (Herdt, 2000).

None of the variables included in the present study affected the occurrence of mastitis during the first two months of lactation. Moreover, there was no association of the BCS at various times after calving with the occurrence of subsequent mastitis during the first three months of lactation.

Neither BUN nor alkaline phosphatase was associated with the occurrence of the diseases evaluated in the present work, which is in alignment with other studies in which BUN levels had a weak negative association with the percentage of endometrial polymorphonuclear leukocytes postpartum in dairy cows (Nazhat et al., 2018). Likewise, Magnus \& Lali (2009) did not observe an association between BUN and postpartum metritis. These findings, however, are not consistent with those of previous studies, which showed that cows with low BUN levels $<9 \mathrm{mg}$ $\mathrm{dL}^{-1}$, in the second and fourth weeks, were at a risk of developing endometritis (Senosy et al., 2012) or metritis (Giuliodori et al., 2013).

The combinations of sensitivity and specificity for the predictor cut points for metritis, clinical endometritis, and clinical ketosis, based on various serum metabolites measured one week postpartum, were considered medium, varying from 54 to $75 \%$ and from 29 to $44 \%$, respectively, but were still valuable for practical use. Those diseases could be detected by screening cows early in lactation or, better yet, prior to parturition through serum BHBA, creatinine, total protein, glucose, cholesterol, and NEFAs.

\section{Conclusions}

1. Serum $\beta$-hydroxybutyrate (BHBA), nonesterified fatty acids, glucose, creatinine, and total protein are useful as diagnostic tests one week postcalving for periparturient diseases in high-yielding Holstein cows in a hot environment.

2. The serum BHBA concentration during the first week post-calving is the most robust indicator of metritis and endometritis, with a high sensitivity.

3 . The body condition score $\leq 3.2$ should be avoided in order to prevent endometritis.

4. Serum glucose $<66.2 \mathrm{mg} \mathrm{dL}^{-1}$ is a suitable predictive value post-calving for the surveillance of cows at risk of developing clinical ketosis.

\section{Acknowledgments}

To Universidad Autónoma Agraria Antonio Narro, for grant; and to the owners and employees of the dairy farm in northern Mexico, for help and support during the study.

\section{References}

BICALHO,M.L.S.; MARQUES,E.C.; GILBERT,R.O.;BICALHO, R.C. The association of plasma glucose, BHBA, and NEFA with postpartum uterine diseases, fertility, and milk production of 
Holstein dairy cows. Theriogenology, v.88, p.270-282, 2017. DOI: https://doi.org/10.1016/j.theriogenology.2016.09.036.

BISINOTTO, R.S.; GRECO, L.F.; RIBEIRO E.S.; MARTINEZ, N.; LIMA, F.S.; STAPLES, C.R.; THATCHER, W.W.; SANTOS, J.E.P. Influences of nutrition and metabolism on fertility of dairy cows. Animal Reproduction, v.9, p.260-272, 2012.

BUSANELLO, M.; ROSSI, R.S.; CASSOLI, L.D.; PANTOJA, J.C.F.; MACHADO, P.F. Estimation of prevalence and incidence of subclinical mastitis in a large population of Brazilian dairy herds. Journal of Dairy Science, v.100, p.6545-6553, 2017. DOI: https://doi.org/10.3168/jds.2016-12042.

CARLOTTI, A.P.C.P.; BOHN, D.; MATSUNO, A.K.; PASTI, D.M.; GOWRISHANKAR, M.; HALPERIN, M.L. Indicators of lean body mass catabolism: emphasis on the creatinine excretion rate. QJM: An International Journal of Medicine, v.101, p.197205, 2008. DOI: https://doi.org/10.1093/qjmed/hcm127.

CHAPINAL, N.; CARSON, M.; DUFFIELD, T.F.; CAPEL, M.; GODDEN, S.; OVERTON, M.; SANTOS, J.E.P.; LEBLANC, S.J. The association of serum metabolites with clinical disease during the transition period. Journal of Dairy Science, v.94, p.48974903, 2011. DOI: https://doi.org/10.3168/jds.2010-4075.

CRAY, C.; ZAIAS, J.; ALTMAN, N.H. Acute phase response in animals: a review. Comparative Medicine, v.59, p.517-526, 2009.

DAS, R.; SAILO, L.; VERMA, N.; BHARTI, P.; SAIKIA, J.; IMTIWATI; KUMAR, R. Impact of heat stress on health and performance of dairy animals: a review. Veterinary World, v.9, p.260-268, 2016. DOI: https://doi.org/10.14202/ vetworld.2016.260-268.

DERVISHI, E.; ZHANG, G.; HAILEMARIAM, D.; GOLDANSAZ, S.A.; DENG, Q.; DUNN, S.M.; AMETAJ, B.N. Alterations in innate immunity reactants and carbohydrate and lipid metabolism precede occurrence of metritis in transition dairy cows. Research in Veterinary Science, v.104, p.30-39, 2016. DOI: https://doi.org/10.1016/j.rvsc.2015.11.004.

DUFFIELD, T.F.; LISSEMORE, K.D.; MCBRIDE, B.W.; LESLIE, K.E. Impact of hyperketonemia in early lactation dairy cows on health and production. Journal of Dairy Science, v.92, p.571-580, 2009. DOI: https://doi.org/10.3168/jds.2008-1507.

EDMONSON, A.J.; LEAN, I.J.; WEAVER, L.D.; FARVER, T.; WEBSTER, G. A body condition scoring chart for Holstein dairy cows. Journal of Dairy Science, v.72, p.68-78, 1989. DOI: https://doi.org/10.3168/jds.S0022-0302(89)79081-0.

ESPOSITO, G.; IRONS, P.C.; WEBB, E.C.; CHAPWANYA, A. Interactions between negative energy balance, metabolic diseases, uterine health and immune response in transition dairy cows. Animal Reproduction Science, v.144, p.60-71, 2014. DOI: https://doi.org/10.1016/j.anireprosci.2013.11.007.

FIORE, E.; PICCIONE, G.; RIZZO, M.; MORGANTE, M.; BARBERIO, A.; GIUDICE, E.; GIANESELLA, M. Adaptation of some energetic parameters during transition period in dairy cows. Journal of Applied Animal Research, v.46, p.402-405, 2018. DOI: https://doi.org/10.1080/09712119.2017.1313742.
FRANKLIN, S.T.; YOUNG, J.W.; NONNECKE, B.J. Effects of ketones, acetate, butyrate, and glucose on bovine lymphocyte proliferation. Journal of Dairy Science, v.74, p. 2507-2514, 1991.

GIULIODORI, M.J.; MAGNASCO, R.P.; BECU-VILLALOBOS, D.; LACAU-MENGIDO, I.M.; RISCO, C.A.; DE LA SOTA, R.L. Metritis in dairy cows: risk factors and reproductive performance. Journal of Dairy Science, v.96, p.3621-3631, 2013. DOI: https://doi.org/10.3168/jds.2012-5922.

GOBIKRUSHANTH, M.; SALEHI, R.; AMBROSE, D.J.; COLAZO, M.G. Categorization of endometritis and its association with ovarian follicular growth and ovulation, reproductive performance, dry matter intake, and milk yield in dairy cattle. Theriogenology, v.86, p.1842-1849, 2016. DOI: https://doi.org/10.1016/j.theriogenology.2016.06.003.

GORDON, J.L.; LEBLANC, S.J.; DUFFIELD, T.F. Ketosis treatment in lactating dairy cattle. Veterinary Clinics of North America: Food Animal Practice, v.29, p.433-445, 2013. DOI: https://doi.org/10.1016/j.cvfa.2013.03.001.

HAMMON, D.S.; EVJEN, I.M.; DHIMAN, T.R.; GOFF, J.P.; WALTERS, J.L. Neutrophil function and energy status in Holstein cows with uterine health disorders. Veterinary Immunology and Immunopathology, v.113, p.21-29, 2006. DOI: https://doi.org/10.1016/j.vetimm.2006.03.022.

HANSEN, M.; LUND, M.S.; PEDERSEN, J.; CHRISTENSEN, L.G. Gestation length in Danish Holsteins has week genetic associations with stillbirth, calving difficulty, and calf size. Livestock Production Science, v.91, p.23-33, 2004. DOI: https://doi.org/10.1016/j.livprodsci.2004.06.007.

HERDT, T.H. Ruminant adaptation to negative energy balance. Influences on the etiology of ketosis and fatty liver. The Veterinary Clinics of North America: Food Animal Practice, v.16, p.215230, 2000. DOI: https://doi.org/10.1016/S0749-0720(15)30102-X

HIITIÖ, H.; VAKKAMÄKI, J.; SIMOJOKI, H.; AUTIO, T.; JUNNILA, J.; PELKONEN, S.; PYÖRÄLÄ, S. Prevalence of subclinical mastitis in Finnish dairy cows: changes during recent decades and impact of cow and herd factors. Acta Veterinaria Scandinavica, v.59, art.22, 2017. DOI: https://doi.org/10.1186/ s13028-017-0288-X.

HOEBEN, D.; MONFARDINI, E.; OPSOMER, G.; BURVENICH, C.; DOSOGNE, H.; DE KRUIF, A.; BECKERS, J.-F. Chemiluminescence of bovine polymorphonuclear leucocytes during the periparturient period and relation with metabolic markers and bovine pregnancy-associated glycoprotein. Journal of Dairy Research, v.67, p.249-259, 2000. DOI: https://doi.org/10.1017/s0022029900004052.

INGVARTSEN, K.L.; MOYES, K. Nutrition, immune function and health of dairy cattle. Animal, v.7, p.112-122, 2013. DOI: https://doi.org/10.1017/S175173111200170X.

JINGAR, S.C.; MEHLA, R.K.; SINGH, M. Climatic effects on occurrence of clinical mastitis in different breeds of cows and buffaloes. Archivos de Zootecnia, v.63, p.473-482, 2014. DOI: https://doi.org/10.4321/S0004-05922014000300008.

KADIVAR, A.; AHMADI, M.R.; VATANKHAH, M. Associations of prepartum body condition score with occurrence of clinical endometritis and resumption of postpartum ovarian activity in

Pesq. agropec. bras., Brasília, v.55, e01308, 2020

DOI: 10.1590/S1678-3921.pab2020.v55.01308 
dairy cattle. Tropical Animal Health and Production, v.46, p.121126, 2014. DOI: https://doi.org/10.1007/s11250-013-0461-9.

KANEENE, J.B.; MILLER, R.A.; HERDT, T.H.; GARDINER, J.C. The association of serum nonesterified fatty acids and cholesterol, management and feeding practices with peripartum disease in dairy cows. Preventive Veterinary Medicine, v.31, p.59-72, 1997. DOI: https://doi.org/10.1016/S0167-5877(96)01141-5.

KAUFMANN, T.B.; DRILLICH, M.; TENHAGEN, B.-A.; HEUWIESER, W. Correlations between periparturient serum concentrations of non-esterified fatty acids, beta-hydroxybutyric acid, bilirubin, and urea and the occurrence of clinical and subclinical postpartum bovine endometritis. BMC Veterinary Research, v.6, art.47, 2010. DOI: https://doi.org/10.1186/1746-6148-6-47.

KESSLER, E.C.; GROSS, J.J.; BRUCKMAIER, R.M.; ALBRECHT, C. Cholesterol metabolism, transport, and hepatic regulation in dairy cows during transition and early lactation. Journal of Dairy Science, v.97, p.5481-5490, 2014. DOI: https://doi.org/10.3168/jds.2014-7926.

MACRAE, A.I.; BURROUGH, E.; FORREST, J.; CORBISHLEY, A.; RUSSELL, G.; SHAW, D.J. Prevalence of excessive negative energy balance in commercial United Kingdom dairy herds. Veterinary Journal, v.248, p.51-57, 2019. DOI: https://doi.org/10.1016/j.tvj1.2019.04.001.

MACRAE, A.I.; WHITAKER, D.A.; BURROUGH, E.; DOWELL, A.; KELLY, J.M. Use of metabolic profiles for the assessment of dietary adequacy in UK dairy herds. Veterinary Record, v.159, p.655-661, 2006. DOI: https://doi.org/10.1136/ vr.159.20.655.

MAGNUS, P.K.; LALI, F.A. Serum biochemical profile of postpartum metritic cow. Veterinary World, v.2, p.27-28, 2009. DOI: https://doi.org/10.5455/vetworld.2009.27-28.

MCART, J.A.A.; NYDAM, D.V.; OETZEL, G.R.; OVERTON, T.R.; OSPINA, P.A. Elevated non-esterified fatty acids and b-hydroxybutyrate and their association with transition dairy cow performance. Veterinary Journal, v.198, p.560-570, 2013. DOI: https://doi.org/10.1016/j.tvj1.2013.08.011.

NAZHAT, S.A.; KITAHARA, G.; KOZUKA, N.; MIDO, S.; SADAWY, M.; ALI, H.E.-S.; OSAWA, T. Associations of periparturient plasma biochemical parameters, endometrial leukocyte esterase and myeloperoxidase, and bacterial detection with clinical and subclinical endometritis in postpartum dairy cows. Journal of Veterinary Medical Science, v.80, p.302-310, 2018. DOI: https://doi.org/10.1292/jvms.17-0478.

NRC. Nutrient Requirements of Dairy Cattle. $7^{\text {th }}$ rev. ed. National Academy Press: Washington, 2001.

OHTSUKA, H.; KASE, H.; ANDO, T.; KOHIRUIMAKI, M.; MASUI, M.; WATANABE, D.; HAYASHI, T.; KAWAMURA, $\mathrm{S}$. Changes in peripheral blood mononuclear cells after calving in lactating cows with serious decrease of body weight before and after calving. Journal of Veterinary Medical Science, v.70, p.153-158, 2008. DOI: https://doi.org/10.1292/jvms.70.153.

OSPINA, P.A.; NYDAM, D.V.; STOKOL, T.; OVERTON, T.R. Evaluation of nonesterified fatty acids and $\beta$-hydroxybutyrate in transition dairy cattle in the northeastern United States: critical thresholds for prediction of clinical diseases. Journal of Dairy
Science, v.93, p.546-554, 2010. DOI: https://doi.org/10.3168/ jds.2009-2277.

RIBEIRO, E.S.; LIMA, F.S.; GRECO, L.F.; BISINOTTO, R.S.; MONTEIRO, A.P.A.; FAVORETO, M.; AYRES, H.; MARSOLA, R.S.; MARTINEZ, N.; THATCHER, W.W.; SANTOS, J.E.P. Prevalence of periparturient diseases and effects on fertility of seasonally calving grazing dairy cows supplemented with concentrates. Journal of Dairy Science, v.96, p.5682-5697, 2013. DOI: https://doi.org/10.3168/jds.2012-6335.

ROCHE, J.R.; FRIGGENS, N.C.; KAY, J.K.; FISHER, M.W.; STAFFORD, K.J.; BERRY, D.P. Invited review: Body condition score and its association with dairy cow productivity, health, and welfare. Journal of Dairy Science, v.92, p.5769-5801, 2009.

SCHUENEMANN, G.M.; NIETO, I.; BAS, S.; GALVÃO, K.N.; WORKMAN, J. Assessment of calving progress and reference times for obstetric intervention during dystocia in Holstein dairy cows. Journal of Dairy Science, v.94, p.5494-5501, 2011. DOI: https://doi.org/10.3168/jds.2011-4436.

SENOSY, W.S.; IZAIKE, Y.; OSAWA, T. Influences of metabolic traits on subclinical endometritis at different intervals postpartum in high milking cows. Reproduction in Domestic Animals, v.47, p.666-674, 2012. DOI: https://doi.org/10.1111/j.14390531.2011.01941.x.

SHELDON, I.M.; LEWIS, G.S.; LEBLANC, S.; GILBERT, R.O. Defining postpartum uterine disease in cattle. Theriogenology, v.65, p.1516-1530, 2006. DOI: https://doi.org/10.1016/j. theriogenology.2005.08.021.

SHIN, E.-K.; JEONG, J.-K.; CHOI, I.-S.; KANG, H.-G.; HUR, T.-Y.; JUNG, Y.-H.; KIM, I.-H. Relationships among ketosis, serum metabolites, body condition, and reproductive outcomes in dairy cows. Theriogenology, v.84, p.252-260, 2015. DOI: https://doi.org/10.1016/j.theriogenology.2015.03.014.

SUNDRUM, A. Metabolic disorders in the transition period indicate that the dairy cows' ability to adapt is overstressed. Animals, v.5, p.978-1020, 2015. DOI: https://doi.org/10.3390/ ani5040395.

THOMPSON, I.M.T.; TAO, S.; MONTEIRO, A.P.A.; JEONG, K.C.; DAHL, G.E. Effect of cooling during the dry period on immune response after Streptococcus uberis intramammary infection challenge of dairy cows. Journal of Dairy Science, v.97, p.7426-7436, 2014. DOI: https://doi.org/10.3168/jds.2013-7621.

TITGEMEYER, E.C.; LÖEST, C.A. Amino acid nutrition: demand and supply in forage-fed ruminants. Journal of Animal Science, v.79, p.E180-E189, 2001. Supplement. DOI: https://doi.org/10.2527/jas2001.79E-SupplE180x.

TÓTHOVÁ, C.; MUDROŇ, P.; NAGY, O. The electrophoretic pattern of serum proteins in dairy cows with inflammatory diseases. Acta Veterinaria-Beograd, v.67, p.178-190, 2017. DOI: https://doi.org/10.1515/acve-2017-0016.

TSENKOVA, R.; ATANASSOVA, S.; KAWANO, S.; TOYODA, K. Somatic cell count determination in cow's milk by near-infrared spectroscopy: a new diagnostic tool. Journal of Animal Science, v.79, p.2550-2557, 2001. DOI: https://doi.org/10.2527/2001.79102550x. 
WANKHADE, P.R.; MANIMARAN, A.; KUMARESAN, A.; JEYAKUMAR, S.; RAMESHA, K.P.; SEJIAN, V.; RAJENDRAN, D.; VARGHESE, M.R. Metabolic and immunological changes in transition dairy cows: a review. Veterinary World, v.10, p.1367-1377, 2017. DOI: https://doi.org/10.14202\%2Fvetworld.2017.1367-1377.

ZARRIN, M.; WELLNITZ, O.; VAN DORLAND, H.A.; BRUCKMAIER R.M. Induced hyperketonemia affects the mammary immune response during lipopolysaccharide challenge in dairy cows. Journal of Dairy Science, v.97, p.330-339, 2014.

DOI: https://doi.org/10.3168/jds.2013-7222.

ZHANG, Y.D.; BU, D.P.; LI, S.C.; ZHENG, N.; ZHOU, X.Q.; ZHAO, M.; ZHAO, S.G.; LI, S.L.; WANG, J.Q. Technical note: can tail arterial or tail venous blood represent external pudic arterial blood to measure amino acid uptake by mammary gland of cows? Livestock Science, v.188, p.9-12, 2016. DOI: https://doi.org/10.1016/j.livsci.2016.03.015. 